\title{
Angiotensin II Receptor Antagonist Attenuates Expression of Aging Markers in Diabetic Mouse Heart
}

\author{
Rie Kosugi, MD; Tetsuo Shioi, MD ; Kayo Watanabe-Maeda, MD; Yuki Yoshida, MD; \\ Keiko Takahashi, BS; Yoji Machida, MD; Tohru Izumi, MD
}

\begin{abstract}
Background Diabetes mellitus is an independent risk factor for heart failure. Diabetes mellitus causes other age-related cardiovascular diseases. We assessed the hypothesis that hearts from diabetic animals are associated with accelerated aging processes. We also examined the effect of an angiotensin II receptor blocker (ARB) on the expression of senescence-associated molecules.

Methods and Results We administered an ARB (candesartan $10 \mathrm{mg} / \mathrm{kg}$ per day) or saline to diabetic $\mathrm{db} / \mathrm{db}$ or control db/+ mice. The treatment was started when mice were 10 -weeks-old, and continued for 15 weeks. Systolic function was impaired in $\mathrm{db} / \mathrm{db}$ mice and candesartan improved cardiac function. The amount of phosphorylated Akt and S6 was decreased in saline-treated $\mathrm{db} / \mathrm{db}$ mice, and candesartan treatment partially preserved phosphorylation. The amount of p21, p27, p53 or Rb was increased in the heart tissue of saline treated db/db mice. Candesartan treatment completely suppressed the increases of p21, p27, p53 and Rb.

Conclusions An ARB improved cardiac function of diabetic animals, and this was accompanied by decreases of senescence-associated molecules in the myocardium. ARB may be a modality for heart failure patients with diabetes mellitus. (Circ J 2006; 70: 482-488)
\end{abstract}

Key Words: Aging; Diabetes; Heart failure; Signal transduction

$\mathbf{E}$ pidemiologic studies have clearly demonstrated that diabetic patients are at increased risk for cardiovascular morbidity and mortality!,2 As diabetes mellitus is associated with several age-related disease, such as atherosclerosis, hypertension and heart failure, diabetes mellitus is considered to be a model of accelerated aging? Diabetes is an independent risk factor for heart failure. Although coronary artery disease is likely to be a major cause of heart failure in diabetes, abnormalities of the myocardium are also suggested to be implicated as a cause of heart failure in diabetic patients?, 6 Congestive heart failure is an age-related disorder, and age is an independent risk factor for heart failure?

The renin-angiotensin system has been shown to be increased in tissues of aged animals? Inhibition of the renin-angiotensin system prevented the development of age-related cardiovascular diseases? Blockade of the reninangiotensin system decreased the number of newly onset diabetic patients! ${ }^{10,11}$ Thus, it might be possible that angiotensin II is involved in the development of diabetes and aging.

We assessed the hypothesis that hearts from diabetic animals are associated with an accelerated aging process.

(Received September 20, 2005; revised manuscript received January 13, 2006; accepted January 19, 2006)

Department of Internal Medicine and Cardiology, Kitasato University School of Medicine, Sagamihara, Japan

Mailing address: Tetsuo Shioi, MD, PhD, Department of Internal Medicine and Cardiology, Kitasato University School of Medicine, 115-1, Kitasato, Sagamihara 228-8555, Japan. E-mail: tshioi@med. kitasato-u.ac.jp

$\dagger$ Current address: Tetsuo Shioi, MD, PhD, Department of Cardiovascular Medicine, Graduate School of Medicine, Kyoto University, 54 Kawaracho, Shogoin, Sakyo-ku, Kyoto 606-8507, Japan. E-mail: tshioi@kuhp.kyoto-u.ac.jp
To examine the hypothesis, we measured the amount of cell cycle inhibiters, which are known to be increased because of the association with cellular senescence and organismal aging! ${ }^{2-14} \mathrm{We}$ also examined the effect of an angiotensin II receptor blocker (ARB) on cardiac function and expression of senescence-associated molecules in the hearts of diabetic animals.

\section{Methods}

\section{Animals}

Adult obese male mice (C57BL/6J db/db) at 8 weeks old were purchased from Charles River (Kanagawa, Japan). Animal care and experimentation methods were approved by the Institutional Animal Care and Use Committee of Kitasato University. Both $\mathrm{db} /+$ mice and $\mathrm{db} / \mathrm{db}$ mice were given saline or candesartan cilexetil $(10 \mathrm{mg} / \mathrm{kg}$ per $\mathrm{ml}$, Takeda, Osaka, Japan) in drinking water beginning when they were 10 weeks old; this continued for 15 weeks.

\section{Hemodynamics}

Systolic blood pressure and heart rate was recorded by the tail cuff method without anesthesia (Softron BP-98A, Tokyo, Japan) ${ }^{15}$ For measuring systolic blood pressure, mice were placed in a warm chamber maintained at $40^{\circ} \mathrm{C}$ for $10 \mathrm{~min}$ in an individual restrainer. The tail cuff device was placed around the mouse's tail. Three pressure measurements were recorded for each mouse, and the average systolic blood pressure was calculated for each mouse.

\section{Echocardiography}

Transthoracic echocardiographic analysis was performed with ProSound SSD-4000 (ALOKA, Tokyo, Japan), with a $7.5-\mathrm{MHz}$ imaging transducer. Briefly, mice were anesthetized with an intraperitoneal injection of ketamine 
Table 1 Hemodynamic Data of $\mathrm{db} / \mathrm{db}$ Mice Treated With Candesartan

\begin{tabular}{lcccccc}
\hline \hline & \multicolumn{2}{c}{ Saline } & & \multicolumn{2}{c}{ Candesartan } \\
\cline { 2 - 3 } \cline { 6 - 7 } & $d b /+$ & $d b / d b$ & & & $d b /+$ & $d b / d b$ \\
\hline No. animals & 10 & 10 & & 10 & 10 \\
Blood pressure (mmHg) & $130 \pm 7$ & $127 \pm 8$ & & $115 \pm 12^{\dagger}$ & $124 \pm 10$ \\
Heart rate (beats/min) & $548 \pm 123$ & $591 \pm 78$ & & & $620 \pm 65$ & $596 \pm 53$ \\
\hline
\end{tabular}

Hemodynamic data of $d b /+$ and $d b / d b$ mice without anesthesia. Values are presented as mean $\pm S E M .{ }^{\dagger} p<0.05$ vs saline treated mice of the same genotype.

Table 2 Postmortem Analysis of $\mathrm{db} / \mathrm{db}$ Mice Treated With Candesartan

\begin{tabular}{|c|c|c|c|c|}
\hline & \multicolumn{2}{|c|}{ Saline } & \multicolumn{2}{|c|}{ Candesartan } \\
\hline & $d b /+$ & $d b / d b$ & $d b /+$ & $d b / d b$ \\
\hline No. animals & 19 & 20 & 20 & 17 \\
\hline Body weight $(g)$ & $31.5 \pm 0.5$ & $45.5 \pm 1.5^{*}$ & $29.9 \pm 0.4$ & $43.3 \pm 1.8^{*}$ \\
\hline Heart weight $(\mathrm{mg})$ & $142.7 \pm 1.5$ & $130.3 \pm 2.7 *$ & $132.7 \pm 2.0^{\dagger}$ & $132.7 \pm 2.0$ \\
\hline Liver weight (mg) & $1,210.9 \pm 42.0$ & $2,384.1 \pm 75.2 *$ & $1,266.3 \pm 27.2$ & $2,354.4 \pm 104.5 *$ \\
\hline Lung weight (mg) & $143.3 \pm 5.5$ & $135.1 \pm 3.4$ & $140.7 \pm 3.6$ & $134.5 \pm 7.0$ \\
\hline Tibial length $(\mathrm{mm})$ & $18.2 \pm 0.2$ & $17.5 \pm 0.1$ & $18.3 \pm 0.1$ & $17.5 \pm 0.1$ \\
\hline Liver weight/bodyweight $(\mathrm{mg} / \mathrm{g})$ & $38.5 \pm 1.7$ & $53.1 \pm 1.8 *$ & $42.6 \pm 1.2$ & $54.5 \pm 1.7 *$ \\
\hline Lung weight/bodyweight $(\mathrm{mg} / \mathrm{g})$ & $4.6 \pm 0.2$ & $3.1 \pm 0.1$ & $4.7 \pm 0.1$ & $3.2 \pm 0.1$ \\
\hline Heart weight/bodyweight $(\mathrm{mg} / \mathrm{g})$ & $4.5 \pm 0.1$ & $2.9 \pm 0.1 *$ & $4.4 \pm 0.1$ & $3.0 \pm 0.1 *$ \\
\hline Liver weight/tibial length $(\mathrm{mg} / \mathrm{mm})$ & $66.7 \pm 2.3$ & $136.3 \pm 4.4^{*}$ & $69.3 \pm 1.5$ & $126.8 \pm 9.1 *$ \\
\hline Lung weight/tibial length $(\mathrm{mg} / \mathrm{mm})$ & $7.9 \pm 0.3$ & $7.7 \pm 0.2$ & $7.7 \pm 0.2$ & $7.2 \pm 0.6$ \\
\hline Heart weight/tibial length $(\mathrm{mg} / \mathrm{mm})$ & $7.9 \pm 0.1$ & $7.4 \pm 0.1 *$ & $7.3 \pm 0.1^{\dagger}$ & $6.9 \pm 0.4^{*}$ \\
\hline
\end{tabular}

Values are presented as mean \pm SEM. ${ }^{*} p<0.05 v s d b /+$ mice with the same treatment. ${ }^{\dagger} p<0.05$ vs saline treated mice of the same genotype.

$(50 \mathrm{mg} / \mathrm{kg})$ and xylazin $(10 \mathrm{mg} / \mathrm{kg})$. An M-mode echocardiogram was obtained at the papillary muscle level, and left ventricular end-diastolic dimension, end systolic dimension and left ventricular posterior wall thickness were measured. Fractional shortening was calculated as described ${ }^{16}$

\section{Blood and Plasma Glucose Concentration}

Before ARB treatment, blood glucose after $12 \mathrm{~h}$ of fasting was measured using Medisafe Mini (TERUMO Co, Tokyo, Japan). At the end of the treatment, mice were anesthetized after $12 \mathrm{~h}$ of fasting and blood was drawn from the inferior vena cava. Plasma glucose concentration was measured by using the Glu-DH method (SRL Inc, Tokyo, Japan).

\section{Plasma Insulin Concentration}

To measure the plasma insulin concentration in mice, a mouse insulin ELISA kit (Ultra-sensitivity) was used (Shibayagi Co, Shibukawa, Gunma, Japan).

\section{Western-Blotting}

The hearts of test mice were removed and immediately frozen in liquid nitrogen. Five mice hearts were used for each group and tissue lysate were individually prepared as described 16 For analysis of p70 S6 kinase (S6K1) phosphorylation, the blots were probed with anti-phospho-S6K1 (Thr 389) antibody (1:200; Cell Signaling, Beverly, MA, USA) or anti-S6K1 antibody (1:200; Santa Cruz, Santa Cruz, CA, USA). For analysis of S6 phosphorylation, the blots were probed with anti-phospho-S6 protein (Ser 235/236) antibody (1:500; Cell Signaling), or anti-glyceraldehyde-3-phosphate dehydrogenase antibody (GAPDH) (1:5,000; Research Diagnostics, Flanders, NJ, USA). For analysis of Akt phosphorylation, the blots were probed with anti-phospho-Akt (Ser 473) antibody (1:500; Cell Signaling) or anti-Akt antibody (1:500; Cell Signaling).
For analysis of extracellularly responsive kinase (ERK) phosphorylation, the blots were probed with anti-phosphoERK antibody (1:200; Santa Cruz) or anti-ERK2 antibody (1:200; Transduction Lab, Lexington, KY, USA). For analysis of $\mathrm{p} 21$ expression, the blots were probed with anti-p21 antibody (1:500; Pharmigen, San Diego, CA, USA) or antiGAPDH antibody. For analysis of p27 expression, the blots were probed with anti-p27 antibody (1:200; Santa Cruz) or anti-GAPDH antibody. For analysis of p53 expression, the blots were probed with anti-p53 antibody (1:500; Cell Signaling) or anti-GAPDH antibody. For analysis of $\mathrm{Rb}$ expression, the blots were probed with Rb antibody (1:500; Santa Cruz) or anti-GAPDH antibody.

\section{Northern Hybridization Analysis}

Total RNA was purified from mouse heart tissue using the acid guanidinium-phenol-chloroform method. Five mice hearts were used for each group and total RNA was individually prepared. An equal amount of total RNA was mixed for each group. Twenty microgram of total RNA of each group were electrophoresed in 1.3\% denaturing formaldehyde agarose gel and blotted with Hybond $\mathrm{N}$ (Amersham, Buckinghamshire, England, UK). The membrane was probed with mouse probes for brain natriuretic peptide (BNP) cDNA as described!6 Blots were washed twice at $50^{\circ} \mathrm{C}$ in $2 \times$ standard saline citrate (SSC) $/ 1 \%$ sadium dodecyl sulface (SDS) for $5 \mathrm{~min}$, and twice at $50^{\circ} \mathrm{C}$ in $2 \times \mathrm{SSC} / 1 \% \mathrm{SDS}$ for $10 \mathrm{~min}$.

\section{Immunofluorescence Study}

Heart tissue was embedded in O.C.T. compound, snapfrozen on dry ice, and stored at $-70^{\circ} \mathrm{C}$. Tissue was sectioned on a cryostat at $10 \mu \mathrm{m}$ and then fixed for $5 \mathrm{~min}$ in acetone at $4^{\circ} \mathrm{C}$. The sections were incubated with anti-p53 antibody (rabbit IgG, Santa Cruz) and anti-actinin antibody (mouse IgG, Sigma) at $4^{\circ} \mathrm{C}$ overnight. Next, sections were incu- 
Table 3 Echocardiographic Data of db/db Mice Treated With Candesartan

\begin{tabular}{|c|c|c|c|c|}
\hline & \multicolumn{2}{|c|}{ Saline } & \multicolumn{2}{|c|}{ Candesartan } \\
\hline & $d b /+$ & $d b / d b$ & $d b /+$ & $d b / d b$ \\
\hline No. animals & 18 & 20 & 20 & 17 \\
\hline Diastolic anterior wall thickness $(\mathrm{mm})$ & $0.9 \pm 0.0$ & $0.9 \pm 0.0$ & $0.9 \pm 0.0$ & $0.8 \pm 0.0$ \\
\hline Diastolic posterior wall thickness $(\mathrm{mm})$ & $0.9 \pm 0.0$ & $1.0 \pm 0.0$ & $0.9 \pm 0.0$ & $0.9 \pm 0.0$ \\
\hline LV diastolic diameter $(\mathrm{mm})$ & $2.4 \pm 0.1$ & $2.0 \pm 0.1 *$ & $2.1 \pm 0.1$ & $1.8 \pm 0.1$ \\
\hline LV systolic diameter $(\mathrm{mm})$ & $1.3 \pm 0.1$ & $1.2 \pm 0.1$ & $1.4 \pm 0.1$ & $1.0 \pm 0.1$ \\
\hline Fractional shortening (\%) & $44.6 \pm 2.0$ & $37.2 \pm 1.8^{*}$ & $46.3 \pm 2.0$ & $42.5 \pm 2.0$ \\
\hline Heart rate (beats/min) & $306 \pm 25$ & $282 \pm 21$ & $282 \pm 24$ & $345 \pm 21$ \\
\hline
\end{tabular}

Cardiac function was analyzed by using echocardiography under anesthesia. Values are presented as mean \pm SEM. $* p<0.05 v \mathrm{~s}$ $d b /+$ mice with the same treatment. $L V$, left ventricle.

Table 4 Concentrations of Plasma Glucose and Insulin of db/db Mice Treated With Candesartan

\begin{tabular}{lcccccc}
\hline \hline & \multicolumn{2}{c}{ Saline } & & \multicolumn{2}{c}{ Candesartan } \\
\cline { 2 - 3 } \cline { 6 - 7 } & $d b /+$ & $d b / d b$ & & & $d b /+$ & $d b / d b$ \\
\hline No. animals & 8 & 10 & & 10 & 9 \\
Blood glucose $(\mathrm{mg} / \mathrm{dl})$ & $188.2 \pm 26.6$ & $1,090.9 \pm 44.9^{*}$ & & & $110.3 \pm 6.24^{\dagger}$ & $1,101.1 \pm 34.5^{*}$ \\
Insulin $(\mu \mathrm{U} / \mathrm{ml})$ & $2.8 \pm 0.2$ & $22.9 \pm 6.4^{*}$ & & & $2.5 \pm 0.1$ & $6.5 \pm 0.2^{*},{ }^{\dagger}$ \\
\hline
\end{tabular}

Values are presented as mean $\pm S E M .{ }^{*} p<0.05 v s d b /+$ mice with the same treatment; ${ }^{\dagger} p<0.05 v s$ saline treated mice of the same genotype.

bated with fluorescent isothiocyanate-labeled anti-rabbit $\mathrm{IgG}$ and rhodamine labeled anti-mouse IgG antibodies at room temperature for $30 \mathrm{~min}$. Nuclei were stained using TOTO-3 (Invitorogen, Carlsbad, CA, USA). Sections were analyzed by confocal microscopy (Carl Zeiss, Oberkochen, Germany).

\section{Statistical Analysis}

All values are expressed as mean \pm SEM. Differences between the groups were compared using Student's t-tests. $\mathrm{P}<0.05$ was considered as significant.

\section{Results}

\section{Hemodynamic Analysis}

Blood pressure of saline-treated $\mathrm{db} /+$ mice was not different from that of saline-treated $\mathrm{db} / \mathrm{db}$ mice (Table 1 ). The blood pressure of candesartan-treated $\mathrm{db} /+$ mice was decreased by $13 \%$ compared with saline-treated $\mathrm{db} /+$ mice $(115 \pm 12 \mathrm{mmHg}$ vs $130 \pm 7 \mathrm{mmHg}, \mathrm{p}<0.05)$. The blood pressure of candesartan-treated $\mathrm{db} / \mathrm{db}$ mice was not significantly different from that of saline-treated $\mathrm{db} / \mathrm{db}$ mice.

\section{Postmortem Analysis}

Body weight was increased by $44 \%$ in saline-treated $\mathrm{db} / \mathrm{db}$ mice compared with saline-treated $\mathrm{db} /+$ mice $(31.5 \pm$ $0.5 \mathrm{~g}$ vs $45.5 \pm 1.5 \mathrm{~g}, \mathrm{p}<0.05$, Table 2 ). Candesartan treatment did not affect the bodyweight of $\mathrm{db} / \mathrm{db}$ mice. The heart weight of saline-treated $\mathrm{db} / \mathrm{db}$ mice was decreased by $9 \%$ compared with saline-treated $\mathrm{db} /+$ mice $(130.3 \pm 2.7 \mathrm{mg}$ vs $142.7 \pm 1.5 \mathrm{mg}, \mathrm{p}<0.05$ ). The heart weight/tibial length ratio of saline-treated $\mathrm{db} / \mathrm{db}$ mice was also decreased compared with saline-treated $\mathrm{db} /+$ mice $(7.4 \pm 0.1 \mathrm{mg} / \mathrm{mm}$ vs $7.9 \pm$ $0.1 \mathrm{mg} / \mathrm{mm}, \mathrm{p}<0.05)$. The heart weight of the candesartantreated $\mathrm{db} / \mathrm{db}$ mice was not significantly different from that of saline-treated $\mathrm{db} / \mathrm{db}$ mice.

\section{Echocardiographic Analysis}

The left ventricular end-diastolic dimension of salinetreated $\mathrm{db} / \mathrm{db}$ mice was significantly decreased compared with that of saline-treated $\mathrm{db} /+$ mice $(2.0 \pm 0.1 \mathrm{~mm}$ vs $2.4 \pm$ $0.1 \mathrm{~mm}, \mathrm{p}<0.05$, Table 3$)$. The left ventricular posterior wall thickness of saline-treated $\mathrm{db} / \mathrm{db}$ mice was not different from saline-treated $\mathrm{db} /+$ mice. Fractional shortening of saline-treated db mice was significantly lower than that of saline-treated $\mathrm{db} /+$ mice $(37.2 \pm 1.8 \%$ vs $44.6 \pm 2.0 \%$, $\mathrm{p}<$ $0.05)$. Fractional shortening of candesartan-treated $d b / d b$ mice tended to be higher than that of saline-treated $\mathrm{db} / \mathrm{db}$ mice $(42.5 \pm 2.0 \%$ vs $37.2 \pm 1.8 \%, \mathrm{p}=0.056)$.

\section{Blood Glucose and Insulin Concentration}

We measured the blood glucose level of the salinetreated $\mathrm{db} /+$ group, saline-treated $\mathrm{db} / \mathrm{db}$ group, candesartan-treated $\mathrm{db} /+$ group, and the candesartan-treated $\mathrm{db} / \mathrm{db}$ group ( $\mathrm{n}=5$ for each group) to check if the $\mathrm{db} / \mathrm{db}$ mice were diabetic. Before ARB treatment, the blood glucose levels of the saline-treated $\mathrm{db} /+$ group, saline-treated $\mathrm{db} / \mathrm{db}$ group, candesartan-treated $\mathrm{db} /+$ group, and candesartan-treated $\mathrm{db} / \mathrm{db}$ group was $123.7 \pm 4.5,479.1 \pm 31.1 *, 134.0 \pm 4.2$, and $501.3 \pm 18.1 \mathrm{mg} / \mathrm{dl}{ }^{*}$, respectively $(\mathrm{n}=5$ for each group, $* \mathrm{p}<$ 0.05 vs saline-treated $\mathrm{db} /+$ group). After the treatment, blood was drawn from the inferior vena cava and plasma glucose and insulin concentrations were determined. Plasma glucose of saline-treated $\mathrm{db} / \mathrm{db}$ mice was increased compared with saline-treated $\mathrm{db} /+$ mice $(1,090.9 \pm 44.9 \mathrm{mg} / \mathrm{dl}$ vs $188.2 \pm 26.6 \mathrm{mg} / \mathrm{dl}, \mathrm{p}<0.05$, Table 4$)$. Candesartan treatment did not change the plasma glucose level of $\mathrm{db} / \mathrm{db}$ mice. Plasma glucose of candesartan-treated $\mathrm{db} /+$ mice was lower than that of saline-treated $\mathrm{db} /+$ mice $(110.3 \pm 6.24 \mathrm{mg} / \mathrm{dl}$ vs $188.2 \pm 26.6 \mathrm{mg} / \mathrm{dl}, \mathrm{p}<0.05)$. The insulin concentration of saline-treated $\mathrm{db} / \mathrm{db}$ mice was significantly higher than that of saline-treated $\mathrm{db} /+$ mice $(22.9 \pm 6.4 \mu \mathrm{U} / \mathrm{ml}$ vs $2.8 \pm$ $0.2 \mu \mathrm{U} / \mathrm{ml}, \mathrm{p}<0.05)$. The insulin concentration of candesartan-treated $\mathrm{db} / \mathrm{db}$ mice was lower than that of saline-treated $\mathrm{db} / \mathrm{db}$ mice $(6.5 \pm 0.2 \mu \mathrm{U} / \mathrm{ml}$ vs $22.9 \pm 6.4 \mu \mathrm{U} / \mathrm{ml}, \mathrm{p}<0.05)$. It is reported that $\mathrm{db} /+$ mice were associated with abnormal glucose handling. ${ }^{7}$

Phosphorylation of Akt, S6, S6K1 and ERK

We examined the activation of potential downstream 

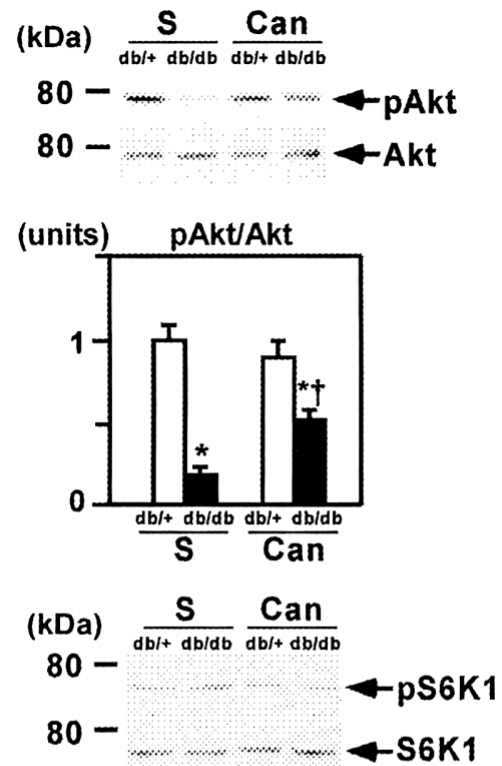

(units) pS6K1/S6K1
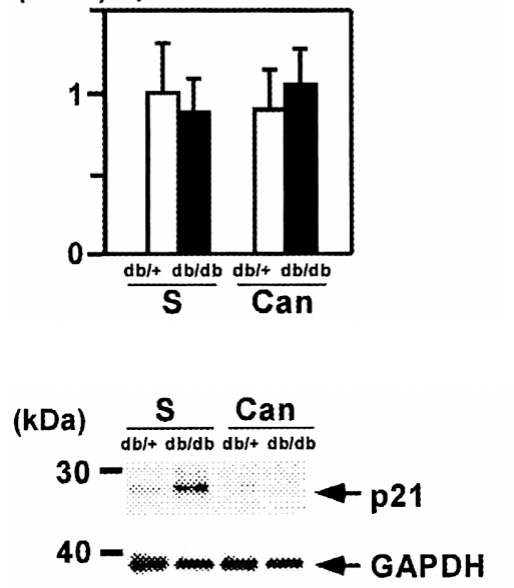

(units) p21/GAPDH

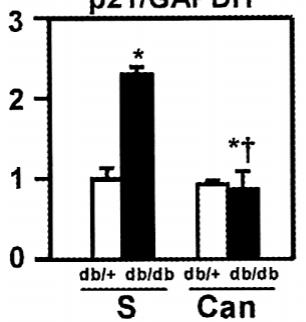

(kDa) $\frac{S}{d b /+d b / d b} \frac{\text { Can }}{d b / d b / d b}$

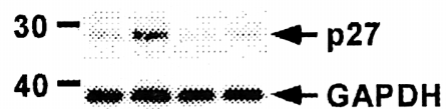

(units)
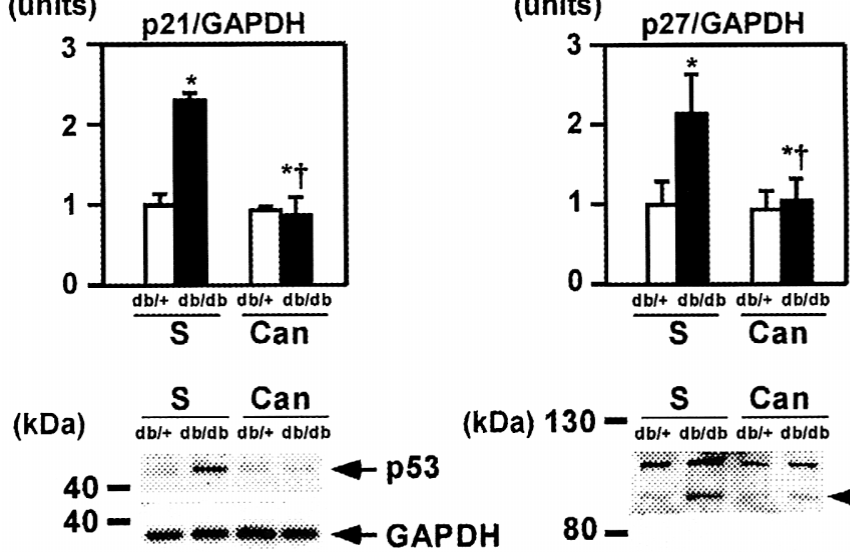

(units)

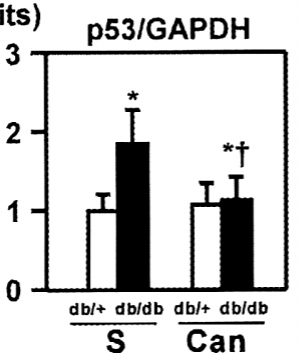

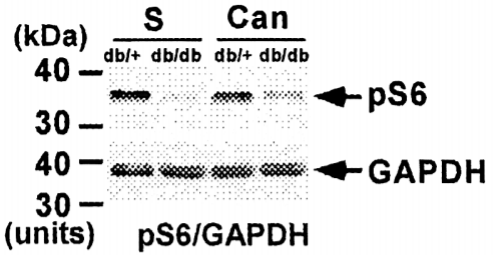

(kDa) $\frac{S}{d b /+d b / d b} \frac{\text { Can }}{d b /+d b / d b}$

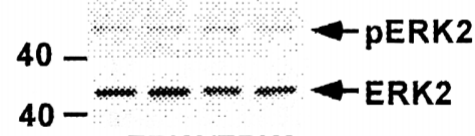

(units) pERK2/ERK2

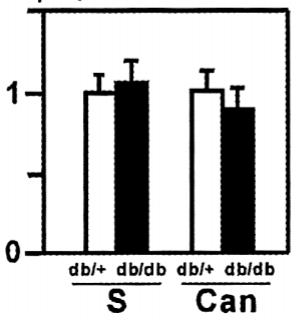

Fig 1. Phosphorylation of Akt, S6 protein, S6K1 or ERK in $\mathrm{db} / \mathrm{db}$ mice. The phosphorylation of Akt, S6, S6K1 and ERK in the heart tissue was analyzed by Western blotting. Representative Western blots are shown in the upper panels and the results of quantitative densitometry of 5 animals in each group are shown in the lower panels. The phosphorylation of Akt was markedly decreased in $\mathrm{db} / \mathrm{db}$ mice compared with $\mathrm{db} /+$ mice, and candesartan treatment partially preserved Akt phosphorylation. The phosphorylation of $\mathrm{S} 6$ was also decreased in $\mathrm{db} / \mathrm{db}$ mice, and candesartan partially preserved the phosphorylation. The phosphorylation of S6K1 and ERK did not change in $\mathrm{db} / \mathrm{db}$ mice. S, saline-treated group; Can, candesartan-treated group; S6K1, S6 kinase; ERK, extracellularly responsive kinase; GAPDH, glyceraldehyde-3-phosphate dehydrogenase. Values are presented as mean \pm SEM. ${ }^{*} \mathrm{p}<0.05 \mathrm{vs} \mathrm{db} /+$ mice with the same treatment. ${ }^{\dagger} \mathrm{p}<0.05$ vs saline-treated mice of the same genotype.
Fig 2. Expression of senescence markers in $\mathrm{db} / \mathrm{db}$ mice. The amount of senescence-associated molecules, p21, p27, p53 or Rb was analyzed by Western blotting. Representative Western blots are shown in the upper panels and the results of quantitative densitometry of 5 animals in each group are shown in the lower panels. The amount of p21, p27, p53 or Rb was increased in the heart tissue of saline-treated $\mathrm{db} / \mathrm{db}$ mice. The candesartan treatment completely suppressed the increases of p21, p27, p53 and Rb. S, saline-treated group; Can, candesartan-treated group; ERK, extracellularly responsive kinase; GAPDH, glyceraldehyde-3-phosphate dehydrogenase. Values are presented as mean \pm SEM. ${ }^{*} \mathrm{p}<0.05 \mathrm{vs} \mathrm{db} /+$ mice with the same treatment. ${ }^{\dagger} \mathrm{p}<0.05$ vs saline-treated mice of the same genotype. 


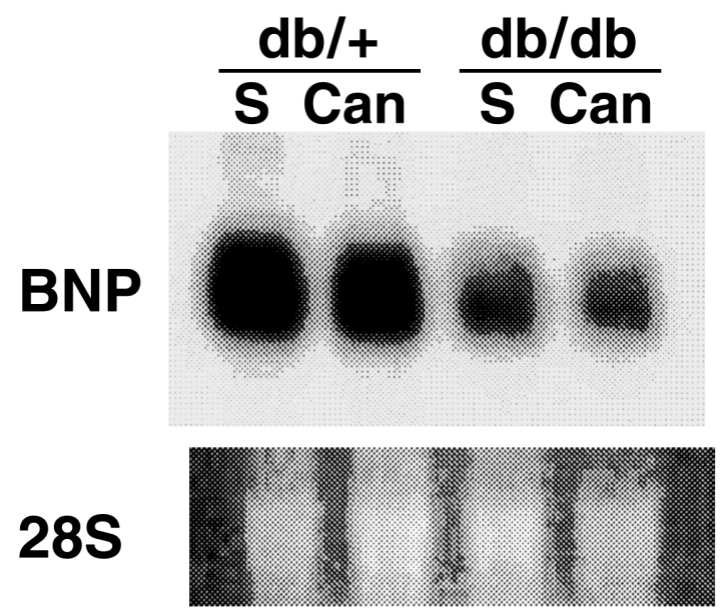

Fig 3. Brain natriuretic peptide (BNP) mRNA expression in the heart tissue of $\mathrm{db} / \mathrm{db}$ mice. BNP mRNA of saline-treated $\mathrm{db} / \mathrm{db}$ mice was decreased compared with saline-treated $\mathrm{db} /+$ mice. Candesartan did not affect BNP gene expression. S, saline-treated group; Can, candesartan-treated group.

targets of an insulin receptor. Representative Western blots are shown in the upper panels of Fig 1 and the results of quantitative densitometry of 5 animals in each group are shown in the lower panels. Akt (or protein kinase B) is one of the best characterized targets of the insulin receptor ${ }^{18}$ Activation of Akt in the heart tissue was assessed by measuring the amount of Akt phosphorylated at Ser473 using a phosphospecific antibody. The amount of phosphorylated Akt was decreased in saline-treated $\mathrm{db} / \mathrm{db}$ mice, and candesartan treatment increased the Akt phosphorylation in $\mathrm{db} / \mathrm{db}$ mice. S6 phosphorylation was decreased in $\mathrm{db} / \mathrm{db}$ mice and candesartan partially preserved the S6 phosphorylation in $\mathrm{db} / \mathrm{db}$ mice. The phosphorylation of S6K1 or ERK did not change between $\mathrm{db} / \mathrm{db}$ and $\mathrm{db} /+$ mice. And candesartan treatment did not affect the phosphorylation of S6K1 or ERK.

\section{Protein Expression of p21, p27, p53 and $R b$}

The amount of cell cycle inhibitors such as p21, p27, $\mathrm{p} 53$ or $\mathrm{Rb}$ increase in cellular senescence ${ }^{14}$ The increase in number of these molecules are also described in the heart tissue of aged animals. ${ }^{13}$ The amount of senescence-associated molecules, p21, p27, p53 or Rb, was analyzed by Western blotting. Representative Western blots are shown in the upper panels of Fig 2 and the results of quantitative densitometry of 5 animals in each group are shown in the lower panels. The amount of p21, p27, p53 or Rb was significantly increased in the heart tissue of saline-treated $\mathrm{db} / \mathrm{db}$ mice. Candesartan treatment almost completely suppressed increases of p21, p27, p53 and Rb.

\section{BNP mRNA Expression}

The BNP mRNA expression of saline-treated $\mathrm{db} / \mathrm{db}$ mice was decreased compared with that of saline-treated $\mathrm{db} /+$ mice. Candesartan did not affect the BNP gene expression in $\mathrm{db} /+$ or $\mathrm{db} / \mathrm{db}$ mice.

\section{Localization of 553 Protein in the Heart Tissue of $d b / d b$ Mice}

Localization of the p53 protein was analyzed by immunofluorescence analysis (Fig 4). Several nuclei of cardiac myocytes were stained with the anti-p53 antibody in a transverse myocardial section of $\mathrm{db} / \mathrm{db}$ mice. No significant signal was observed in the sections of $\mathrm{db} /+$ mice.

\section{Discussion}

In the present study, the cardiac systolic function was significantly decreased in $\mathrm{db} / \mathrm{db}$ mice, and candesartan
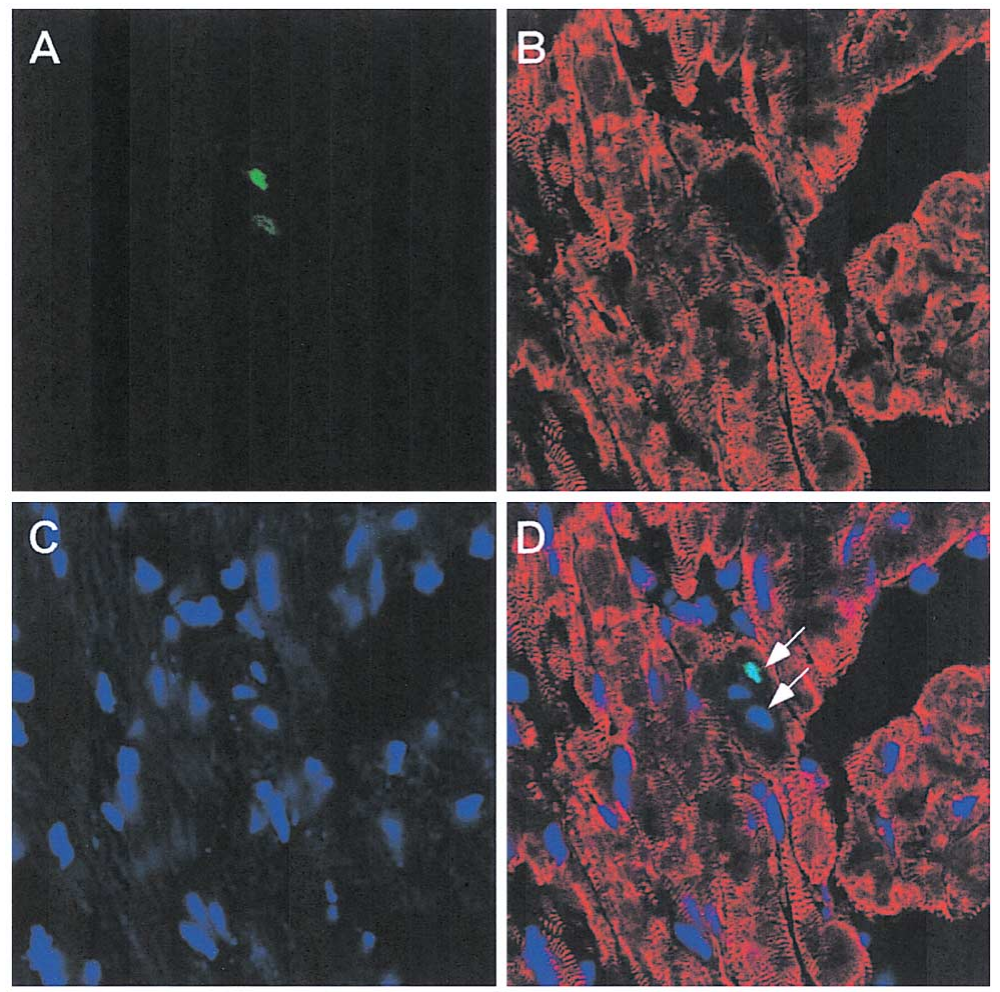

Fig 4. Localization of the p53 protein in the heart tissue of $\mathrm{db} / \mathrm{db}$ mice. Localization of p53 in the myocardium of $\mathrm{db} / \mathrm{db}$ mice was examined by immunofluorescence study. 553 protein was localized in the nuclei of cardiac myocytes (arrows). A, p53; B, actinin; C, nuclei; D, merged image. 
treatment improved cardiac function. Cardiac insulin signaling, assessed by the phoshorylation of Akt or S6, was attenuated in $\mathrm{db} / \mathrm{db}$ mice, and candesartan partially preserved insulin signaling. Senescence-associated molecules were increased in the myocardium of $\mathrm{db} / \mathrm{db}$ mice and candesartan completely suppressed the increase.

The absolute heart weight of $\mathrm{db} / \mathrm{db}$ mice was lower compared with $\mathrm{db} /+$ mice in the present study. Although there has been a report that ob/ob mice at 6-months of age are associated with an increase in heart weight, the heart weight of $\mathrm{db} / \mathrm{db}$ mice aged 2 months is lower in that report 19 There was another report that the absolute heart weight of $\mathrm{db} / \mathrm{db}$ mice is not different from $\mathrm{db} /+$ mice $^{20} \mathrm{We}$ have previously reported that the phosphoinositide 3-kinase pathway is necessary and sufficient to promote heart growth!6 Thus, a decrease in Akt phosphorylation observed in our $\mathrm{db} / \mathrm{db}$ mice might cause a decrease in heart weight.

Insulin signaling in the heart of $\mathrm{db} / \mathrm{db}$ mice is evaluated by measuring the amount of phosphorylated Akt, S6 or S6K1. Phosphorylation of Akt and S6 was decreased in $\mathrm{db} / \mathrm{db}$ mice compared with $\mathrm{db} /+$ mice, and S6K1 phosphorylation was not different from that of $\mathrm{db} /+$ mice. Akt is one of the best characterized targets of the insulin receptor ${ }^{18}$ S6K1 is also a downstream of the insulin receptor, but it is also activated in a insulin signal independent pathway? 21,22 S6K1 is not necessary for S6 phosphorylation in intact tissue ${ }^{23}$ In this experiment, S6K1 activity may be controlled in an insulin signaling independent manner.

Candesartan increased Akt phosphorylation of diabetic $\mathrm{db} / \mathrm{db}$ mice. Recently, a series of studies has revealed a tight connection between the insulin signal transduction pathway and the angiotensin signal transduction pathway. Several studies have suggested that angiotensin II might negatively modulate insulin-mediated actions by regulating several levels of the insulin signaling cascade such as the insulin receptor, insulin receptor substrate, and phosphoinositide 3-kinase ${ }^{24,25}$ Therefore, candesartan might increase Akt phosphorylation by suppressing the angiotensin IIinduced negative regulation of insulin signaling. Alternatively, candesartan may increase Akt phosphorylation in an insulin signaling independent manner because angiotensin II is reported to modulate Akt phosphorylation in a phosphoinositide 3-kinase independent manner ${ }^{26}$

In the present study, candesartan treatment effectively attenuated the increase of senescence-associated molecules in the heart tissue of $\mathrm{db} / \mathrm{db}$ mice. Angiotensin II decreases the telomerase activity of the endothelial progenitor cell and the effect is reversed by superoxide dismutase, suggesting that angiotensin II may induce senescence like phenotype via oxidative stress.7 Angiotensin II is involved in the generation of oxidative stress, 828 and oxidative stress is thought to play a critical role in the aging process ${ }^{29}$ Candesartan may decrease markers of senescence by reducing oxidative stress. In addition, overexpression of insulin-like growth factor-1 in the heart causes an increase in Akt phosphorylation and a decrease in the amount of p21, p27 and p53!3 Thus, it is also possible that preservation of insulin signaling by candesartan may be involved in the decrease of p21, p27, p53 and Rb in the heart tissue of $\mathrm{db} / \mathrm{db}$ mice.

An increase in the amount of the angiotensin-converting enzyme, angiotensinogen, in the tissue of diabetic animals has been reported 30,31 An angiotensin-converting enzyme inhibitor decreased the inflammatory response in the myocardium of diabetic animals?2 An ARB improved cardiac diastolic function and decreased fibrosis of diabetic rats 33 In the present study, cardiac function was impaired in $\mathrm{db} / \mathrm{db}$ mice, which is what was found in previous reports, 34,35 and candesartan treatment improved cardiac function.

The amount of senescence-associated molecules, such as p21, p27, p53 and Rb, were increased in the myocardium of diabetic $\mathrm{db} / \mathrm{db}$ mice. $\mathrm{p} 53$ has been reported to be involved in myocardial damage induced by stretch 36 tachycardia ${ }^{37}$ or renin-angiotensin system activation 38 p53 knockout mice are associated with reduced doxorubicin-induced myocardial dysfunction 39 Thus, the increase of senescence-associated molecules may be involved in the cardiac dysfunction of $\mathrm{db} / \mathrm{db}$ mice, and candesartan may improve cardiac function, in part, by reducing the amount of these senescenceassociated molecules.

BNP mRNA is decreased in the myocardium of $\mathrm{db} / \mathrm{db}$ mice. BNP levels were recently shown to be inversely proportional to the body mass index in individuals without heart failure ${ }^{40,41}$ and in those with chronic heart failure ${ }^{42}$ Obesity is associated with the impaired atrial natriuretic peptide mRNA expression in the hearts of Zucker diabetic rats ${ }^{43}$ suggesting that a decrease in the production of BNP in the myocardium may explain the lower BNP level in the obese population.

Diabetes is associated with several age-related disorders such as cataracts, osteoporosis, or atherosclerosis, raising speculation that diabetes and physiological aging have a common process? Heart failure is an age-associated disorder? In the present study, candesartan partially preserved insulin signaling as measured by the phosphorylation of Akt and S6. In contrast, candesartan completely suppressed the senescence markers. Thus, angiotensin II may be involved in the development of the aging process itself, in addition to the prevention of diabetes.

\section{Acknowledgments}

This study was supported, in part, by grants from the Japan Society for the Promotion of Science (15390252), the Japan Heart Foundation, the Japan Foundation of Cardiovascular Research, the NOVARTIS Foundation for the Promotion of Science, the Mochida Memorial Foundation for Medical and Pharmaceutical Research, the Takeda Medical Research Foundation, the Kanagawa Nanbyo Foundation, the Takeda Science Foundation (to TS), the Japan Society for the Promotion of Science (16590713), and a Postgraduate Research Project of Kitasato University (to TI).

\section{References}

1. Garcia MJ, McNamara PM, Gordon T, Kannel WB. Morbidity and mortality in diabetics in the Framingham population: Sixteen year follow-up study. Diabetes 1974; 23: 105-111.

2. Kannel WB, McGee DL. Diabetes and cardiovascular disease: The Framingham study. JAMA 1979; 241: 2035-2038.

3. Cerami A, Vlassara H, Brownlee M. Glucose and aging. Sci Am 1987; 256: 90-96.

4. Kannel WB, Hjortland M, Castelli WP. Role of diabetes in congestive heart failure: The Framingham study. Am J Cardiol 1974; 34: $29-34$.

5. Fein FS, Sonnenblick EH. Diabetic cardiomyopathy. Prog Cardiovasc Dis 1985; 27: 255-270.

6. Galderisi M, Anderson KM, Wilson PW, Levy D. Echocardiography evidence for the existence of a distinct diabetic cardiomyopathy (the Framingham Heart Study). Am J Cardiol 1991; 68: 85-99.

7. Lakatta EG, Levy D. Arterial and cardiac aging: Major shareholders in cardiovascular disease enterprises: Part II: The aging heart in health: Links to heart disease. Circulation 2003; 107: 346-354.

8. Wang M, Takagi G, Asai K, Resuello RG, Natividad FF, Vatner DE, et al. Aging increases aortic MMP-2 activity and angiotensin II in nonhuman primates. Hypertension 2003; 41: 1308-1316.

9. Brown B, Hall AS. Renin-angiotensin system modulation: The weight of evidence. Am J Hypertens 2005; 18: S127-S133. 
10. Yusuf S, Ostergren JB, Gerstein HC, Pfeffer MA, Swedberg K, Granger CB, et al. Effects of candesartan on the development of a new diagnosis of diabetes mellitus in patients with heart failure. Circulation 2005; 112: 48-53.

11. Abuissa H, Jones PG, Marso SP, O’Keefe JH Jr. Angiotensinconverting enzyme inhibitors or angiotensin receptor blockers for prevention of type 2 diabetes: A meta-analysis of randomized clinical trials. J Am Coll Cardiol 2005; 46: 821-826.

12. Machida S, Booth FW. Increased nuclear proteins in muscle satellite cells in aged animals as compared to young growing animals. Exp Gerontol 2004; 39: $1521-1525$.

13. Torella D, Rota M, Nurzynska D, Musso E, Monsen A, Shiraishi I, et al. Cardiac stem cell and myocyte aging, heart failure, and insulinlike growth factor-1 overexpression. Circ Res 2004; 94: 514-524.

14. Chai W, Shay JW, Wright WE. Human telomeres maintain their overhang length at senescence. Mol Cell Biol 2005; 25: 2158-2168.

15. Bunag RD. Validation in awake rats of a tail-cuff method for measuring systolic pressure. J Appl Physiol 1973; 34: 279-282.

16. Shioi T, Kang PM, Douglas PS, Hampe J, Yballe CM, Lawitts J, et al. The conserved phosphoinositide 3-kinase pathway determines heart size in mice. EMBO J 2000; 19: 2537-2348.

17. Yamashita H, Shao J, Ishizuka T, Klepcyk PJ, Muhlenkamp P, Qiao $\mathrm{L}$, et al. Leptin administration prevents spontaneous gestational diabetes in heterozygous leprdb/+ mice: Effects on placental leptin and fetal growth. Endocrinology 2001; 142: 2888-2897.

18. Chan TO, Rittenhouse SE, Tsichlis PN. AKT/PKB and other D3 phosphoinositide-regulated kinases: Kinase activation by phosphoinositide-dependent phosphorylation. Аппи Rev Biochem 1999; 68: 965-1014.

19. Barouch LA, Berkowitz DE, Harrison RW, O'onnell CP, Hare JM. Distruption of leptin signaling contributes to cardiac hypertrophy independently of body weight in mice. Circulation 2003; 108: 754759.

20. Aasum E, Belke DD, Severson DL, Riemersma RA, Cooper M, Andreassen M, et al. Cardiac function and metabolism in Type 2 diabetic mice after treatment with BM 17.0744, a novel PPAR-alpha activator. Am J Physiol 2002; 283: 949-957.

21. Conus NM, Hemmings BA, Pearson RB. Differential regulation by calcium reveals distinct signaling requirements for the activation of Akt and p70S6k. J Biol Chem 1998; 273: 4776-4782.

22. Ballou LM, Cross ME, Huang S, McReynolds EM, Zhang BX, Lin RZ. Differential regulation of the phosphatidylinositol 3-kinase/Akt and p70 S6 kinase pathways by the alpha(1A)-adrenergic receptor in rat-1 fibroblasts. J Biol Chem 2000; 275: 4803-4809.

23. Pende M, Um SH, Mieulet V, Sticker M, Goss VL, Mestan J, et al. S6K1(-/-)/S6K2(-/-) mice exhibit perinatal lethality and rapamycinsensitive 5'-terminal oligopyrimidine mRNA translation and reveal a mitogen-activated protein kinase-dependent S6 kinase pathway. Mol Cell Biol 2004; 24: 3112-3124.

24. Velloso LA, Folli F, Sun XJ, White MF, Saad MJA, Kahn CR. Cross-talk between the insulin and angiotensin signaling systems. Proc Natl Acad Sci USA 1996; 93: 12490-12495.

25. Folli F, Kahn CR, Hansen H, Bouchie JL, Feener EP. Angiotensin II inhibits insulin signaling in aortic smooth muscle cells at multiple levels. J Clin Invest 1997; 100: 2158-2169.

26. Gorin Y, Kim NH, Feliers D, Bhandari B, Choudhury GG, Abboud HE. Angiotensin II activates Akt/protein kinase B by an arachidonic acid/redox-dependent pathway and independent of phosphoinositide 3-kinase. FASEB J 2001; 15: 1909-1920.
27. Imanishi T, Hano T, Nishio I. Angiotensin II accelerates endothelial progenitor cell senescence through induction of oxidative stress. $J$ Hypertens 2005; 23: $97-104$.

28. Rajagopalan S, Kurz S, Munzel T, Tarpey M, Freeman BA, Griendling $\mathrm{KK}$, et al. Angiotensin II-mediated hypertension in the rat increases vascular superoxide production via membrane NADH/NADPH oxidase activation: Contribution to alterations of vasomotor tone. J Clin Invest 1996; 97: 1916-1923.

29. Balaban RS, Nemoto S, Finkel T. Mitochondria, oxidants, and aging. Cell 2005; 120: 483-495.

30. Awad AS, Webb RL, Carey RM, Siragy HM. Increased renal production of angiotensin II and thromboxane B2 in conscious diabetic rats. Am J Hypertens 2005; 18: 544-548.

31. Kim S, Wanibuchi H, Hamaguchi A, Miura K, Yamanaka S, Iwao H. Angiotensin blockade improves cardiac and renal complications of type II diabetic rats. Hypertension 1997; 30: 1054-1061.

32. Zaman AK, Fujii S, Sawa H, Goto D, Ishimori N, Watano K. Angiotensin-converting enzyme inhibition attenuates hypofibrinolysis and reduces cardiac perivascular fibrosis in genetically obese diabetic mice. Circulation 2001; 103: 3123-3128.

33. Hayashi T, Sohmiya K, Ukimura A, Endoh S, Mori T, Shimomura $\mathrm{H}$, et al. Angiotensin II receptor blockade prevents microangiopathy and preserves diastolic function in the diabetic rat heart. Heart 2003; 89: $1236-1242$

34. Belke DD, Swanson EA, Dillmann WH. Decreased sarcoplasmic reticulum activity and contractility in diabetic $\mathrm{db} / \mathrm{db}$ mouse heart. Diabetes 2004; 53: $3201-3208$.

35. Semeniuk LM, Kryski AJ, Severson DL. Echocardiography assessment of cardiac function in diabetic $\mathrm{db} / \mathrm{db}$ and transgenic $\mathrm{db} / \mathrm{db}$ hGLUT4 mice. Am J Physiol 2002; 283: 976-982.

36. Leri A, Claudio PP, Li Q, Wang X, Reiss K, Wang S, et al. Stretchmediated release of angiotensin II induces myocyte apoptosis by activating p53 that enhances the local renin-angiotensin system and decreases the Bcl2-to-Bax protein ratio in the cell. J Clin Invest 1998; 101: $1326-1342$

37. Leri A, Liu Y, Malhotra A, Li Q, Stiegler P, Claudio PP, et al. Pacinginduced heart failure in dogs enhances the expression of p53 and p53-dependent genes in ventricular myocytes. Circulation 1998; 97: 194-203.

38. Pierzchalski P, Reiss K, Cheng W, Cirielli C, Kajstura J, Nitahara JA, et al. p53 induces myocyte apoptosis via the activation of the reninangiotensin system. Exp Cell Res 1997; 234: 57-65.

39. Shizukuda Y, Matoba S, Mian OY, Nguyen T, Hwang PM. Targeted disruption of p53 attenuates doxorubicin-induced cardiac toxicity in mice. Mol Cell Biochem 2005; 273: 25-32.

40. Wang TJ, Larson MG, Levy D, Leip EP, Benjamin EJ, Wilson PW, et al. Impact of age and sex on plasma natriuretic peptide levels in healthy adults. Am J Cardiol 2002; 90: 254-258.

41. Wang TJ, Larson MG, Levy D, Benjamin EJ, Leip EP, Wilson PW, et al. Impact of obesity on plasma natriuretic peptide levels. Circulation 2004; 109: 594-600.

42. Mehra MR, Uber PA, Park MH, Scott RL, Ventura HO, Harris BC, et al. Obesity and suppressed B-type natriuretic peptide levels in heart failure. J Am Coll Cardiol 2004; 43: 1590-1595.

43. Morabito D, Vallotton MB, Lang U. Obesity is associated with impaired ventricular protein kinase C-MAP kinase signaling and altered ANP mRNA expression in the heart of adult Zucker rats. $J$ Invest Med 2001; 49: 310-318. 